\title{
The microbial nature of laminated limestones: Lessons from the Upper Aptian, Araripe Basin, Brazil
}

\author{
Bruno Catto $^{\mathrm{a}, *}$, Ricardo Jorge Jahnert ${ }^{\mathrm{a}}$, Lucas Verissimo Warren ${ }^{\mathrm{b}}$, Filipe Giovanini Varejao ${ }^{\mathrm{b}}$, Mario Luis Assine ${ }^{\mathrm{b}}$ \\ a Petrobras - Petroleo Brasileiro S.A., Avenida Chile, 330, Rio de Janeiro, RJ, Brazil \\ b UNESP - Universidade Estadual Paulista, Instituto de Geociencias e Ciencias Exatas, Avenida 24A, 1515 Rio Claro, SP, Brazil
}

\section{A R T I C L E I N F O}

\section{Article history:}

Received 10 March 2016

Received in revised form 5 May 2016

Accepted 8 May 2016

Available online 17 May 2016

Editor: Dr. B. Jones

\section{Keywords:}

Araripe basin

Lower Cretaceous carbonate

Laminated limestones

Microbialites

Organomineralization

EPS

\begin{abstract}
A B S T R A C T
The Araripe Basin, located in northeastern Brazil, originated during the Gondwana continental break-up responsible for the opening of the South Atlantic during the Early Cretaceous. In the Araripe Basin, the post-rift Aptian sequence corresponds to the Santana Group, which is composed, in upward succession, of mostly clastic continental and rare carbonate layers of the Barbalha, Crato, Ipubi and Romualdo Formations. The laminated limestones of the Crato Formation were deposited in a lacustrine environment preceding the deposition of the Ipubi Formation evaporites. They are age-equivalent to the limestones of the pre-salt interval of the east coast of Brazil, which contains large petroleum reserves. The excellent preservation of its macrofossils has made the Crato Formation known worldwide as a Fossil Lagerstätte. The limestones are macroscopically homogeneous, and their deposition has been previously attributed to chemical precipitation. Although the carbonate laminites are macroscopically undifferentiated, mineralogical variations, microscopic texture and distinctive biotic aspects supported the characterization of four microfacies: planar laminated, crustiform, nodular and rhythmic. The microfacies analysis indicated a strong and pervasive biological activity in the Crato limestone morphogenesis. Organominerals precipitated by the metabolic action of cyanobacteria and/or sulfate-reducing bacteria and methanogenic-oxidizing archea are represented by calcite and pyrite. Calcified coccoid and filaments are common, furthermore, the presence of calcified biofilms composed of exopolymeric substances (EPS) is ubiquitous. The presence of amorphous organic matter (AOM) and gypsum, particularly in the rhythmic microfacies, indicates anoxic/dysoxic conditions and stressful environments during periods of drought and low lake levels which favored the development and preservation of microbial biofilms. Phytoclasts and miospores when present in the succession indicate an extrabasinal contribution during wetter periods, although the environment remained of very low energy. The evidence of microbial influence in the formation of the laminated limestones of the Crato Formation is of great importance for understanding the excellent preservation of the unit's fossils and for modeling the evolution of the Aptian carbonate sequences in Brazil.
\end{abstract}

(c) 2016 Elsevier B.V. All rights reserved.

\section{Introduction}

The Araripe Basin, located in northeastern Brazil, covers an area of approximately $9000 \mathrm{~km}^{2}$ (Fig. 1). Its origin is related to the Gondwana rifting event and the opening of the South Atlantic Ocean (Matos, 1992, 1999). Similarly to the Brazilian marginal basins, its stratigraphic framework consists of megasequences generated during the rift and post-rift stages. The Aptian post-rift I sequence (Assine, 2007) corresponds to the Santana Group, which consists, in upward succession, of the Barbalha, Crato, Ipubi and Romualdo Formations. The stratigraphic column consists of a transgressive stacking of fluvial facies overlain by

\footnotetext{
* Corresponding author.

E-mail addresses: bruno.catto@petrobras.com.br (B. Catto), jahnert@petrobras.com.br (R.J. Jahnert), warren@rc.unesp.br (L.V. Warren), filipe.varejao@hotmail.com (F.G. Varejao), assine@rc.unesp.br (M.L. Assine).
}

the Crato lacustrine limestones, Ipubi evaporites, and the marine section of the Romualdo Formation (Assine, 1992, 2007).

The depositional environment of the Crato Formation and its excellent preservation of fossils have made it known worldwide as a Cretaceous Fossil Lagerstätte (Martill et al., 2007a). According to Freire et al. (2013), oxygen restriction in a large stratified body of water may be the primary factor for the preservation of the organic content, including soft tissues such as cuticles, muscle fibers and micropapillae (Barling et al., 2015).

The Crato Formation consists of carbonate layers several meters thick interbedded with siliciclastic sediments (shales and sandstones), whose origin is attributed to transgressive-regressive events associated with the expansion and contraction of a lacustrine system (Neumann, 1999). The lacustrine carbonate facies have a calcite composition with low magnesium content and are predominantly composed of micritic laminated limestones (Fig. 2). The origin of the Crato carbonates is 


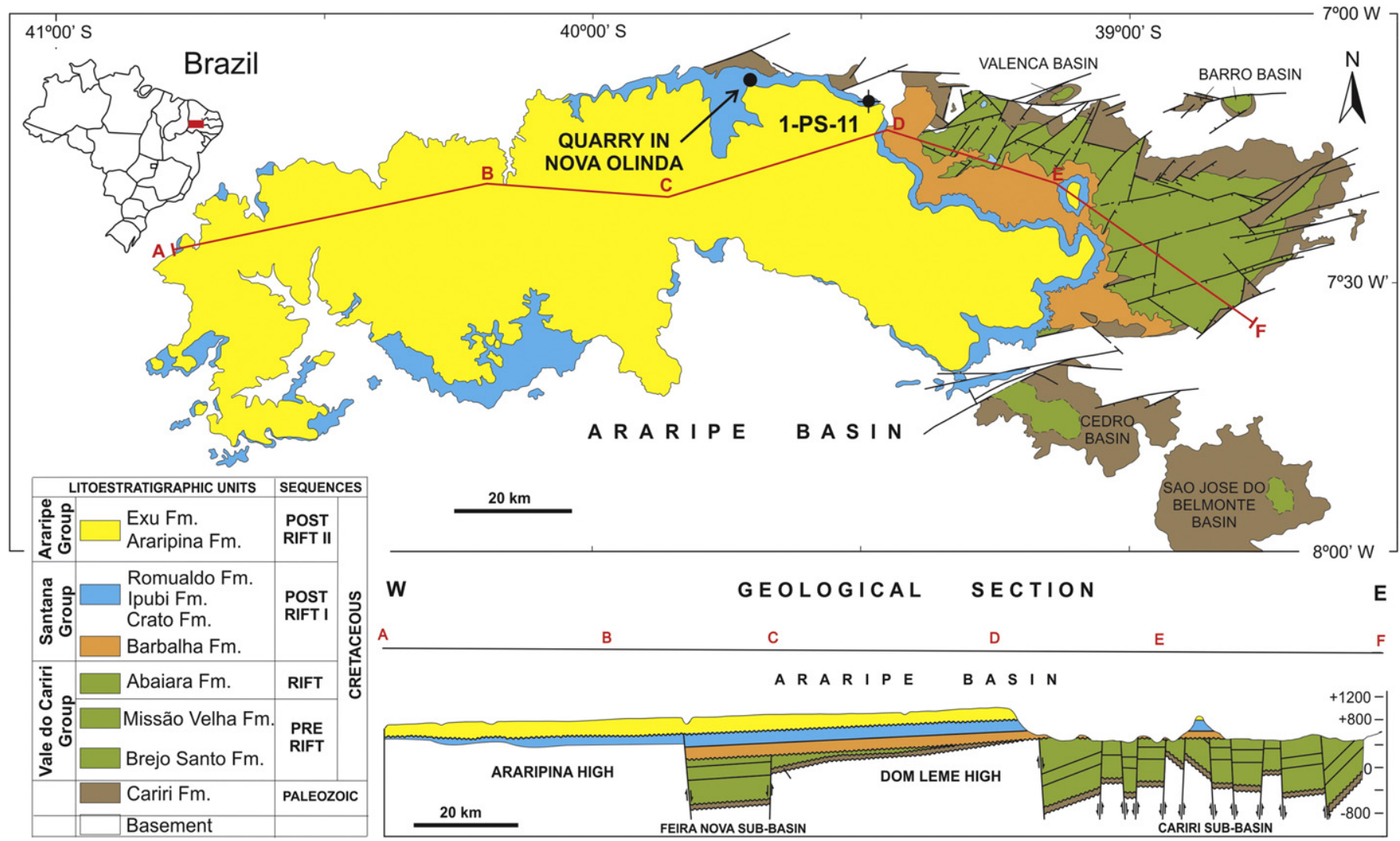

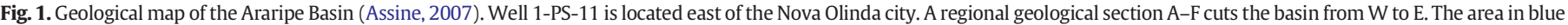
represents the regional extent of the carbonates contained in the Crato Fm.

traditionally attributed to chemical precipitation associated with fine clastic sediments unaffected by any organic mediation (Heimhofer et al., 2010).

The laminated limestones was previously attributed to profundal carbonate facies, which consists of detrital redeposited material from littoral carbonate or transported by turbidite currents, with low organic content remains (Dean and Fouch, 1983).

The goal of this paper is to characterize the carbonate laminites of the Crato Formation in terms of their mineralogy, chemical composition, petrofabric, microstructures and organic content and investigate evidences for the microbial influence on the formation of the Crato Formation limestones. The north-central Araripe basin was chosen as the study area because it contains the best preserved limestones facies in the unit, which are the focus of most published studies of the Crato Formation (Fig. 2). Also the samples of the well 1-PS-11-CE, which was drilled east of the Nova Olinda city, Ceara State (Fig. 1) and intercepted a representative stratigraphic profile of the unit, were carefully analyzed because of their fresh and well preserved carbonates.

\section{Methods and materials}

The sedimentary section sampled by the 1-PS-11-CE well is $73 \mathrm{~m}$ thick and contains five intervals of carbonate rocks of various thicknesses interbedded with siliciclastic intervals. The limestone layer, lying between depths of 130.75 and $137.10 \mathrm{~m}$, was selected for analysis. The limestone section is macroscopically homogeneous, consisting of laminites characterized by alternation of light and dark lenses, responsible for the rhythmicity of the succession. Based on facies variations in the well core, thirteen levels were sampled for thin sections, scanning electron microscope (SEM) and organic and inorganic geochemical analyses.

Classification of the carbonate facies was based on Demicco and Hardie (1994), which includes genetic terms appropriate for the intrabasinal rocks with organic origin. To differentiate carbonate categories produced directly or indirectly by microorganism activity, the classification scheme of Dupraz et al. (2009) involving biologicallyinduced and/or influenced mineralization was applied. The microfacies were defined based on textural features, crystal morphology, and fossil content and diagenetic features from thin sections arrangement, rock samples and polished pieces, in accordance with the modified model of Flügel (2004). The thin-section petrography was conducted using a Zeiss Axio Imager A2 binocular petrographic microscope and a Zeiss Stereo Discovery V.12 binocular magnifying glass.

The thin sections were also analyzed by scanning electron microscopy (Model Zeiss EVO MA15 operated at EHT 20-30 kV and 40-80 Pa pressure). The resulting images were generated in variable-pressure mode, without metal coating. Some samples were initially rinsed with $1 \%$ hydrochloric acid to remove the mineral fraction and to preserve the organic content, a procedure that etches flat surfaces and enables the visualization of three-dimensional morphologic features.

Ten samples were subjected to geochemical analyze to determine the total organic carbon (TOC) using a LECO SC-144 analyzer with an infrared detector. The TOC content was determined by combustion of the pulverized and previously acidified samples with $\mathrm{HCl}$. The noncarbonate portion of the sample not removed by acid treatment was used for analysis of the insoluble residue (IR). Four samples were selected for palynofacies analysis after removal of the mineral matrix. The purpose was to evaluate the organic content in the carbonate rock and to infer its genesis associated with the mineral fraction (Combaz, 

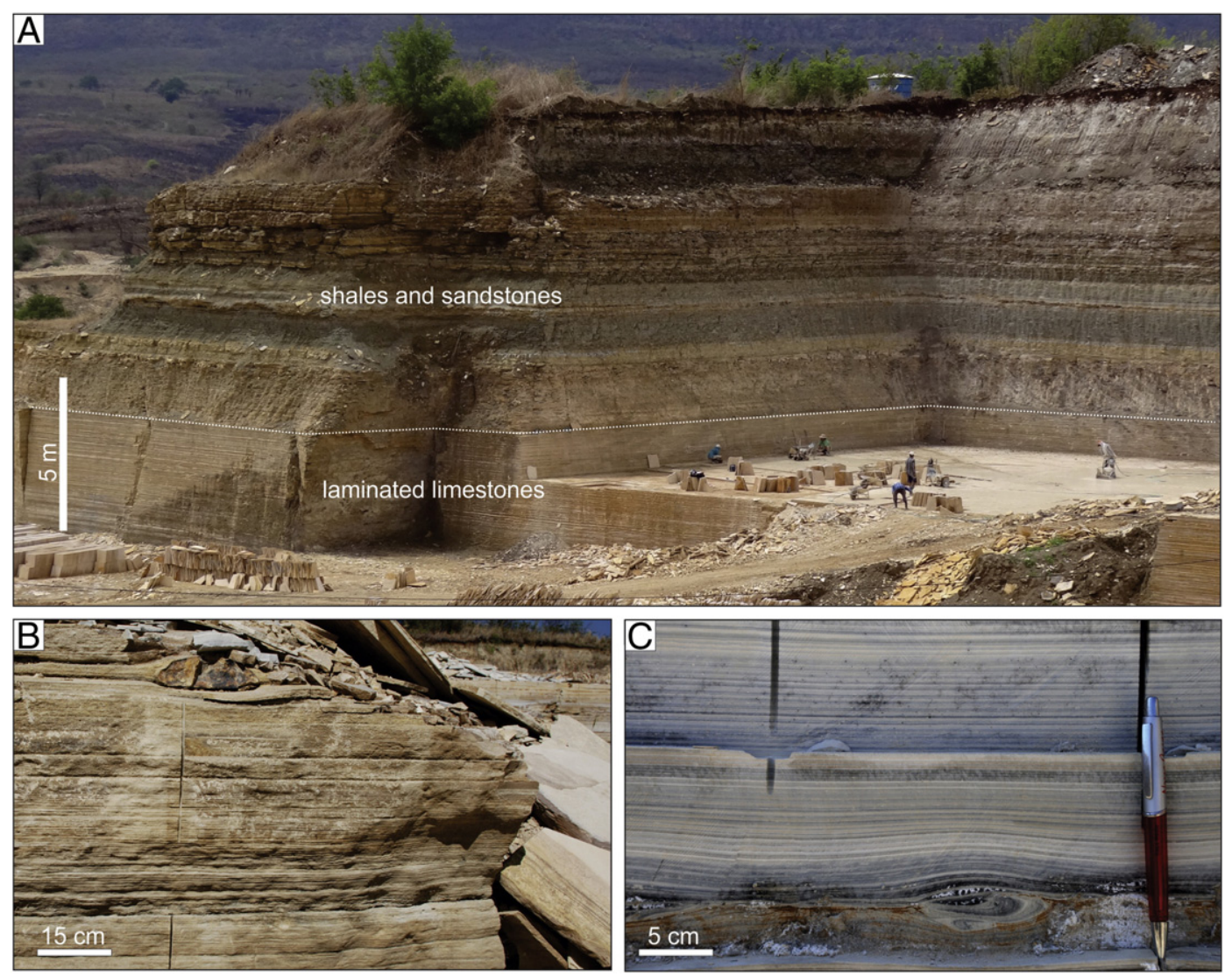

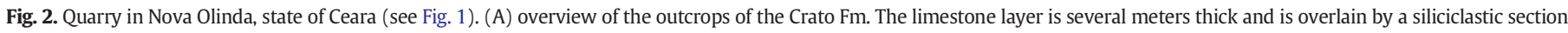
consisting of shales and sandstones; (B and $\mathrm{C}$ ) the limestones display millimetric delicate lamination evident in the photographs at the bottom.

1980). The procedure for evaluating the quality of the kerogen was conducted by counting 300 particles per sample. The isolated organic matter was mounted on glass slides and polished sections for analysis under transmitted, reflected and fluorescent white light. For classification of the kerogen, the identification procedure of Tyson (1993) was adapted to lacustrine systems, discriminating the predominant organic constituents and anoxic conditions.

Some samples were analyzed by X-ray diffraction (XRD) using a Philips/Panalytical PW-1830 diffractometer. Rock powder pellets were burned at $60{ }^{\circ} \mathrm{C}$ and $\mathrm{Cu}$ radiation ( $\left.\mathrm{Cu}-\mathrm{k} \alpha=1.5406 \AA\right)$ and investigated with a scanning interval at angles ranging between $3^{\circ}$ and $70^{\circ}$. Interpretation of the diffractograms and identification of the minerals were performed using the X'Pert High Score software, and the measurements were quantified using the Reitveld method.

$\mathrm{X}$-ray micro-fluorescence analyses ( $\mu$-XRF) were performed using an M4 Tornado from Bruker Corporation to map the areal distribution of chemical elements in certain thin sections.

\section{Results}

The stratigraphic stacking of the Crato Formation is evidenced in the well 1-PS-11-CE by the occurrence of sedimentary sequences composed of shales, at the base, and sandstones and carbonates at the top. The thickest and best developed carbonate interval, according to the log profiles, was chosen for analysis (Fig. 3). This interval is composed of laminated carbonates with variable organic matter richness that responds for the laminae differentiation. The microfacies characterization and organic components provided the basis for paleo-environmental interpretation.

\subsection{Organic components}

The studied carbonate laminites of the Crato Fm. contained low levels of total organic carbon (TOC, generally less than 1\%) and insoluble residue (IR, less than $3 \%$ ), except for the sample at $136.35 \mathrm{~m}$ depth, which contained $6.74 \%$ TOC and 17\% IR (Table 1).

\subsubsection{Description}

The organic components are primarily amorphous organic matter (AOM), with minor phytoclasts and miospores (Fig. 4). Heterogeneous AOM with high fluorescence and poorly defined outer edges is dominant in the interval. Its internal structure is alveolar with a honeycomb texture. Also present is homogenous AOM with well-defined outer edges, dark colors and low fluorescence. The miospores (spores and pollen grains) typically exhibit high fluorescence and form tetrads.

\subsubsection{Interpretation}

The organic components with high fluorescence indicate anoxic conditions during the deposition of the Crato Formation laminites (Neumann et al., 2003). In anoxic-dysoxic environments, the preservation of organic components rich in hydrogen (labile kerogen) is directly related to the intensity of the fluorescence, i.e., the higher the kerogen fluorescence, the greater the preservation of organic matter. The predominance of highly fluorescent AOM, low content of palynomorphs (Table 1) and the tetrads of miospore support the interpretation of low-energy depositional environments with low oxygen content (Tyson, 1984, 1993, 1995). The internal structure of heterogeneous AOM is very similar to features found in extracellular polymeric 


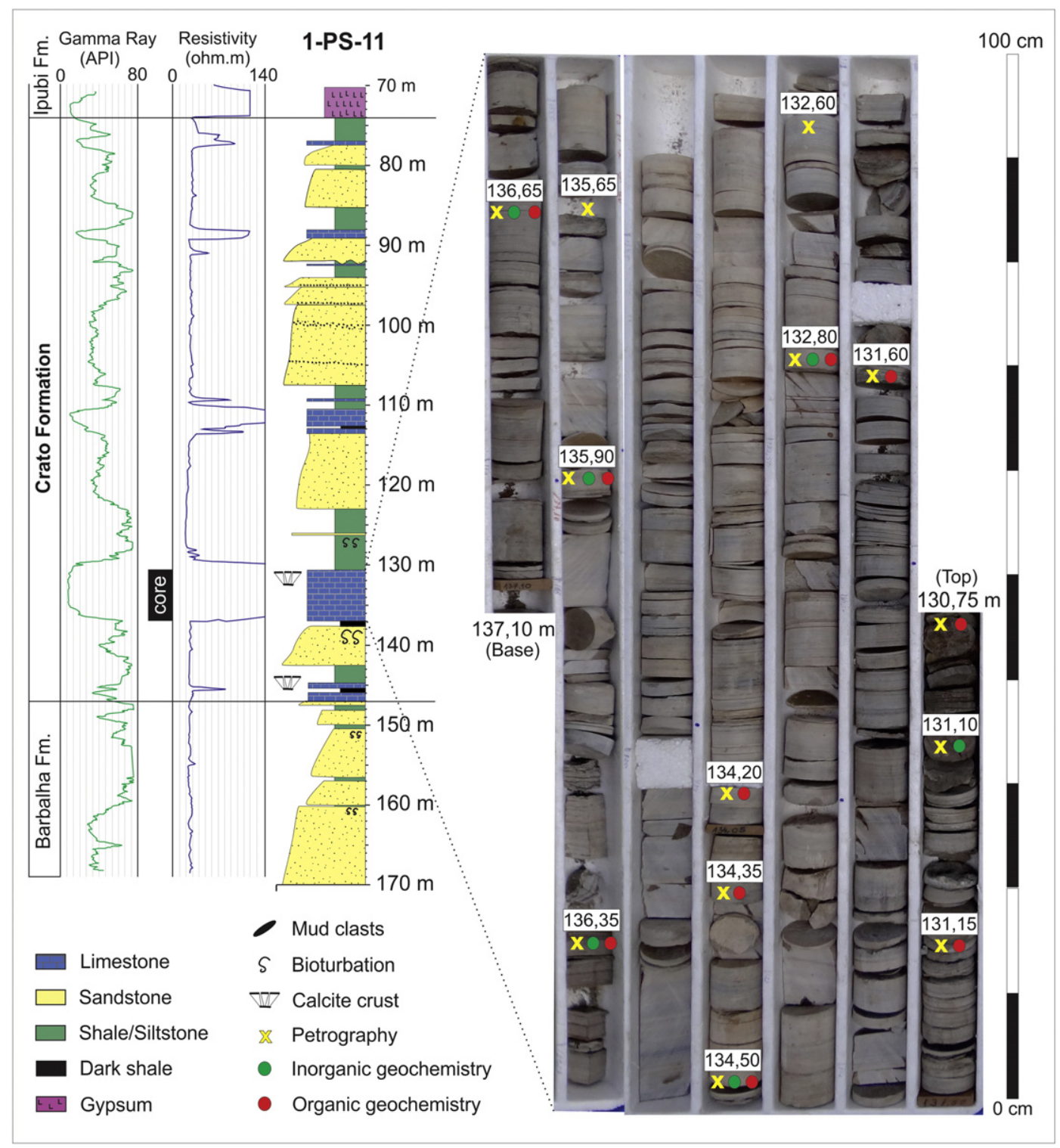

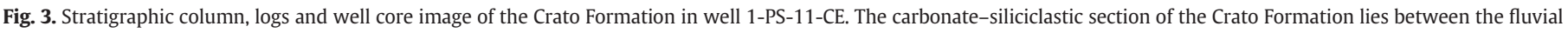

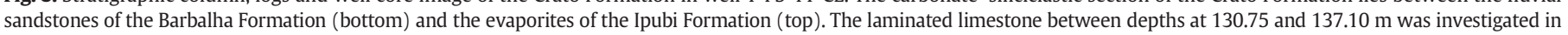
this study.

substances (EPS) and it looks the same feature recognized by Dupraz et al. (2004) in the Bahamas modern environment.

Although the carbonate laminites are macroscopically undifferentiated, variations in mineralogy, microscopic texture, structures and

Table 1

Quantified percentage of total organic carbon (TOC), insoluble residue (IR) and palynofacies of the laminite microfacies $(\mathrm{AOM}=$ amorphous organic matter; FIT $=$ phytoclast and $\mathrm{MI}=$ miospore).

\begin{tabular}{llllll}
\hline Depth $(\mathrm{m})$ & TOC $(\%)$ & IR $(\%)$ & AOM $(\%)$ & FIT $(\%)$ & MI (\%) \\
\hline 130.75 & 0.83 & 3 & 91 & 7 & 2 \\
131.15 & 0.42 & 1 & - & - & - \\
131.60 & 0.70 & 2 & 93 & 3 & 4 \\
132.80 & 0.54 & 1 & - & - & - \\
134.20 & 0.81 & 1 & 92 & 6 & 2 \\
134.35 & 0.62 & 1 & 82 & 8 & 10 \\
134.50 & 0.92 & 1 & - & - & - \\
135.90 & 0.99 & 1 & - & - & - \\
136.35 & 6.74 & 17 & - & - & - \\
136.65 & 1.77 & 2 & - & - & - \\
\hline
\end{tabular}

biota allowed the characterization of four microfacies: rhythmic, nodular, planar laminated and crustiform. These four microfacies, predominantly calcitic, are described and interpreted below.

\subsection{Rhythmic microfacies}

\subsubsection{Description}

The rhythmic microfacies is characterized by interbedded submillimetric to millimetric lenses of micritic calcite, organic matter and clay (Fig. 5). These lenses, which range in thickness from 0.5 to $2.0 \mathrm{~mm}$, form pairs of light and dark micritic lenses with restricted concentrations of organic matter and clay. Micrite is locally recrystallized, forming small crusts of prismatic calcite a few millimeters thick. The dark lenses, which are rich in organic matter, exhibit alveolar structures, spherical to sub-spherical calcite forms (diameter of 1 to $5 \mu \mathrm{m}$ ), and hollow ellipsoids partially filled with microspheres. Along with the calcite crystals calcified filaments are found that resemble tubes in cross section. A few lenses are truncated and exhibit deformation structures as loop-bedding. The XRD analyses revealed the presence of gypsum in this microfacies. 

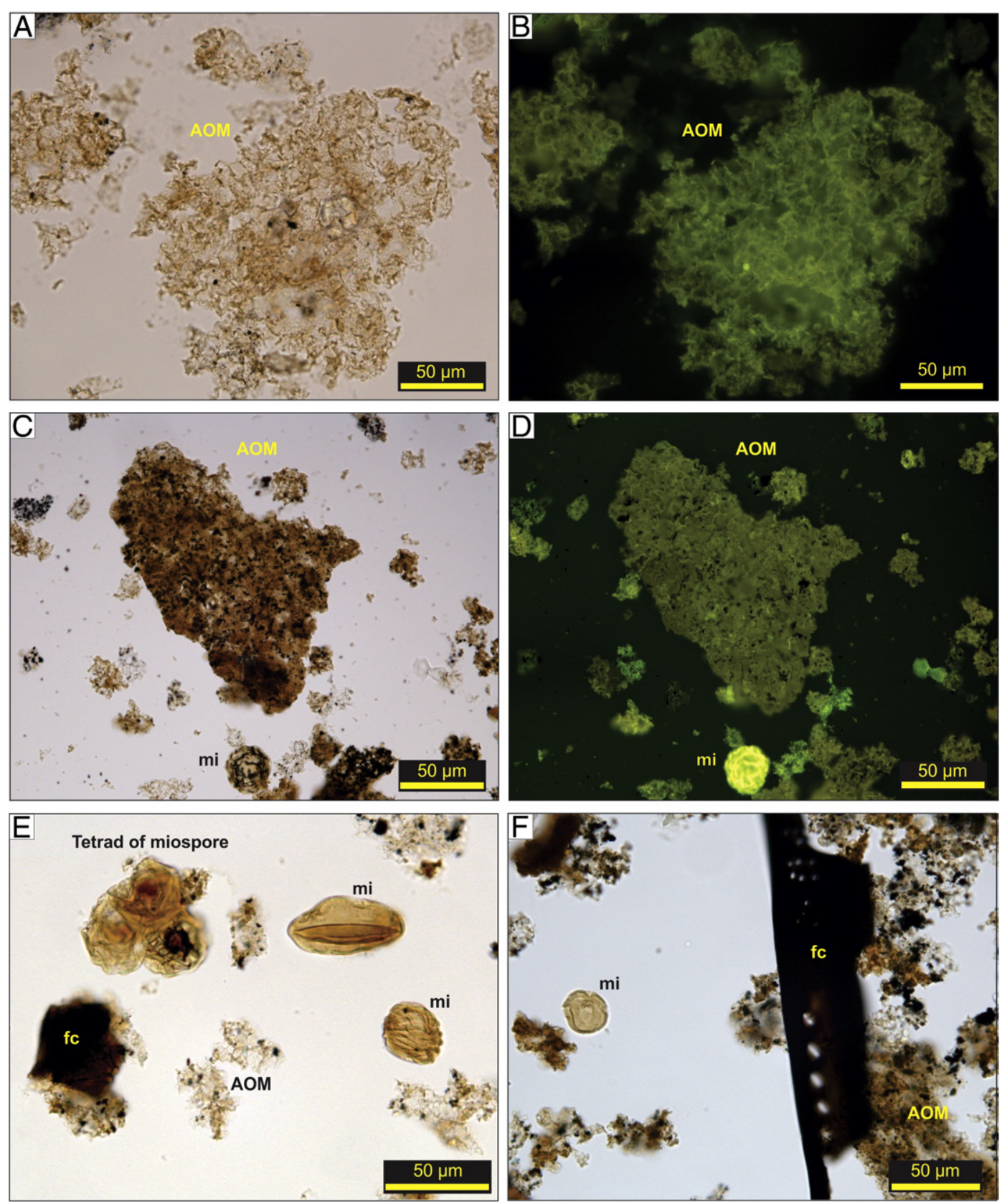

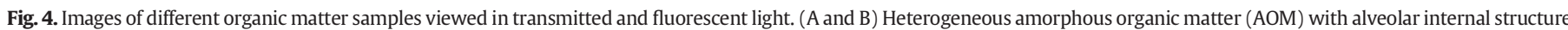

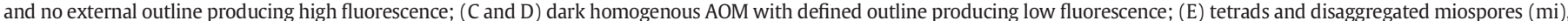
usually producing high fluorescence; (F) structured opaque phytoclasts (fc) complete the palynomorph framework.

\subsubsection{Interpretation}

The alveolar structure is highly suggestive of microbial origin ( $c f$. Dupraz et al., 2004; Pacton et al., 2012; Bahniuk et al., 2015) and is commonly present as an organic matrix consisting of calcified benthic bacteria and mucilage (De Philippis et al., 1998, 2001; Stal, 2000, 2003; Richert et al., 2005). The presence of gypsum suggests a harsh environment for metazoans, thereby decreasing bioturbation and favoring the preservation of laminations in rhythmites (Bowler and Teller, 1986). This environment is, therefore, hostile to predators of microbial mats (such as gastropods and copepods) and provides conditions favorable for the development and preservation of bacteria (Vasconcelos et al., 2006). The micro and nanospheres resemble mineralization in an organic matrix (Braissant et al., 2003; Aloisi et al., 2006). The calcitic filaments may represent the calcification or carbonate incrustation of filamentous bacteria sheaths (Pentecost and Riding, 1986). The presence of pyrite, organic matter with high fluorescence and the preservation quality of the structures and fossils in this stratigraphic interval indicate anoxia during deposition (Freire et al., 2013), or even an anoxic interval below the sediment-water interface. Reducing and hypersaline environments are typical of water bodies that are closed or have restricted water inflow, characterized by high organic productivity within stratified water columns (Tyson, 1993, 1995).

\subsection{Nodular microfacies}

\subsubsection{Description}

The nodular microfacies is characterized by interbedded irregular micritic lenses and organic clays with spherical and/or elongated 

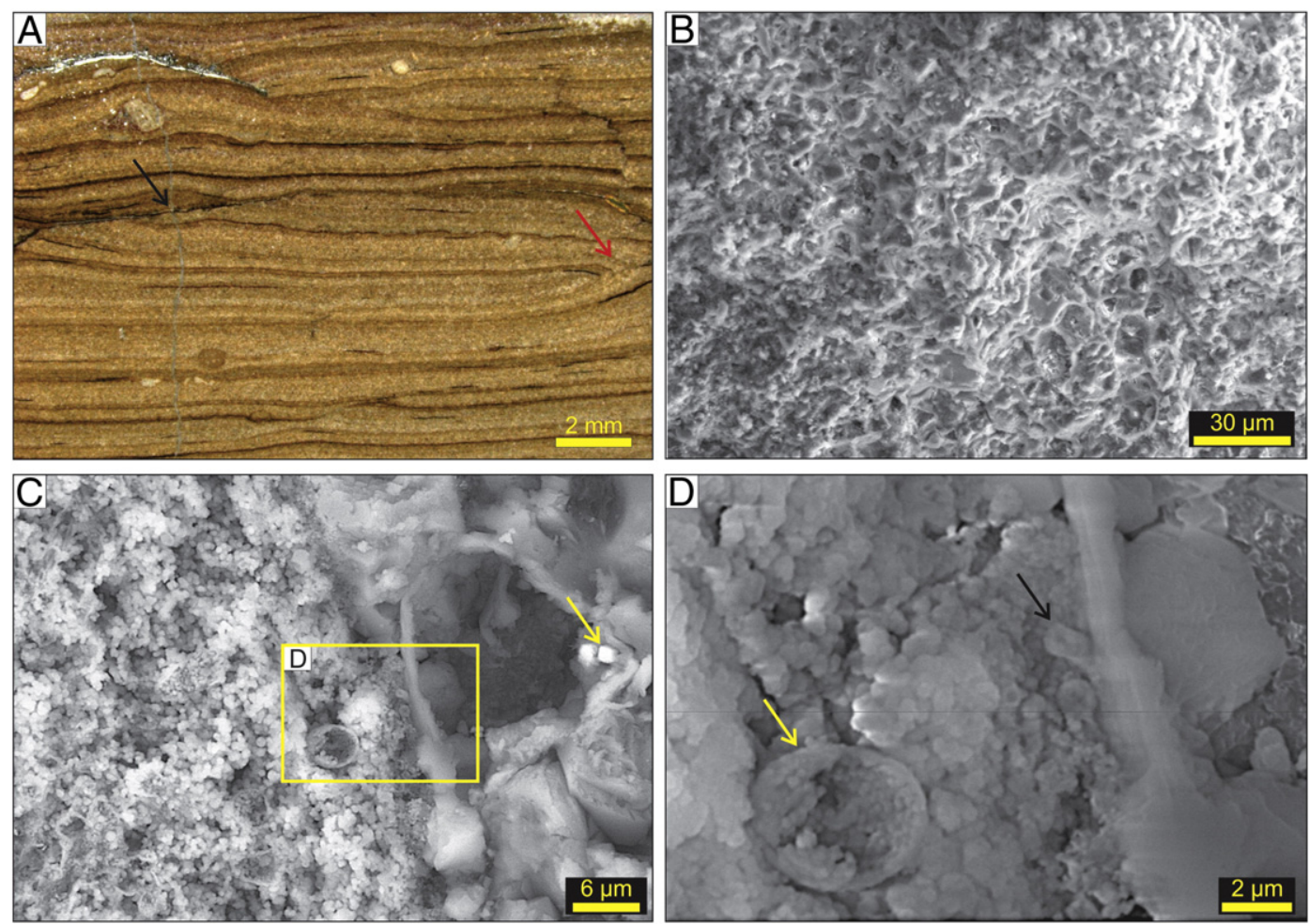

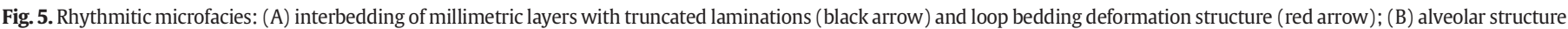

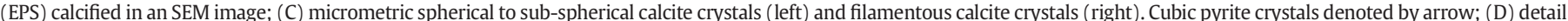
of $\mathrm{C}$ showing a semi ellipsoid surrounded by spherical/sub-spherical aggregates of calcite (yellow arrow). The black arrow points to a cut in a calcified filament, at $136.65 \mathrm{~m}$.
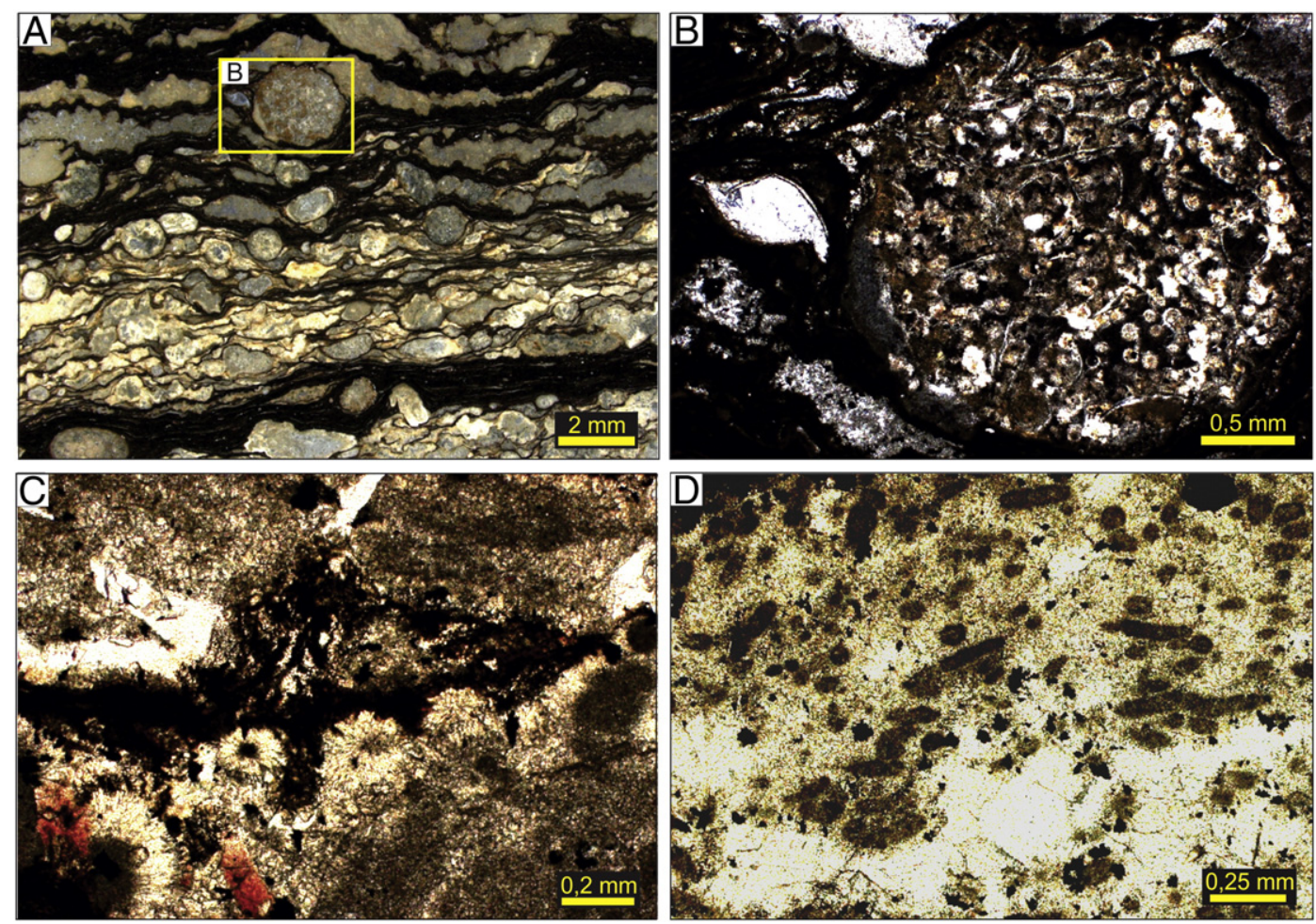

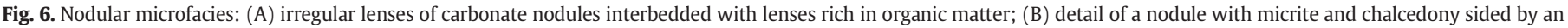

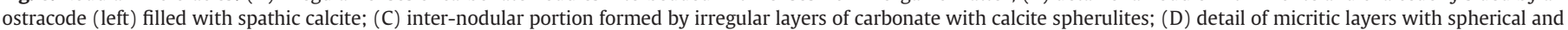
elongated dark morphologies within a substrate where it is possible identify the presence of euhedral to subhedral calcite, at $136.35 \mathrm{~m}$. 
Table 2

Mineral composition (\%) of the carbonate microfacies.

\begin{tabular}{llllll}
\hline \multirow{2}{*}{ Microfacies } & \multicolumn{5}{l}{ Mineralogy (\%) } \\
\cline { 2 - 6 } & Calcite & Pyrite & Gypsite & Quartz & Fluorite \\
\hline Rhythmitic & 95.20 & 1.50 & 3.30 & - & - \\
Nodular & 87.20 & 2.50 & 6.70 & 3.70 & - \\
Planar lamination & 98.10 & 0.90 & - & - & 1.00 \\
Crust & 96.90 & 0.40 & 2.70 & - & - \\
\hline
\end{tabular}

nodules concordant with the lamination (Fig. 6). The nodules composed of micrite and quartz deform the micritic and carbonaceous lenses. The irregular carbonate layers are composed of calcite spherulites and a peloidal matrix. The matrix is constituted of spherical and elongated peloids, with portions consisting of recrystallized euhedral to subhedral calcite. This microfacies contains the greatest amounts of gypsum (6.74\%) and pyrite (2.50\%) among the four microfacies (Table 2). The organic lenses are millimetric in thickness and contain TOC concentrations as high as $6.74 \%$ (Table 1). SEM images allowed the identification of several dark spherical and filamentous shapes, including possibly a calcified Spirulina cyanobacteria (Fig. 7). Calcite microspheres (approximately $20 \mu \mathrm{m}$ in diameter) with smooth surfaces are abundant and form aggregates within a spathic cement. A few of the microspheres are perfect spheres; others form conjugate pairs of varying size. Individual or pairs of equal-sized spheres are present as internal moldings in the spathic cement. Calcite spheres with radiating-fiber internal structures
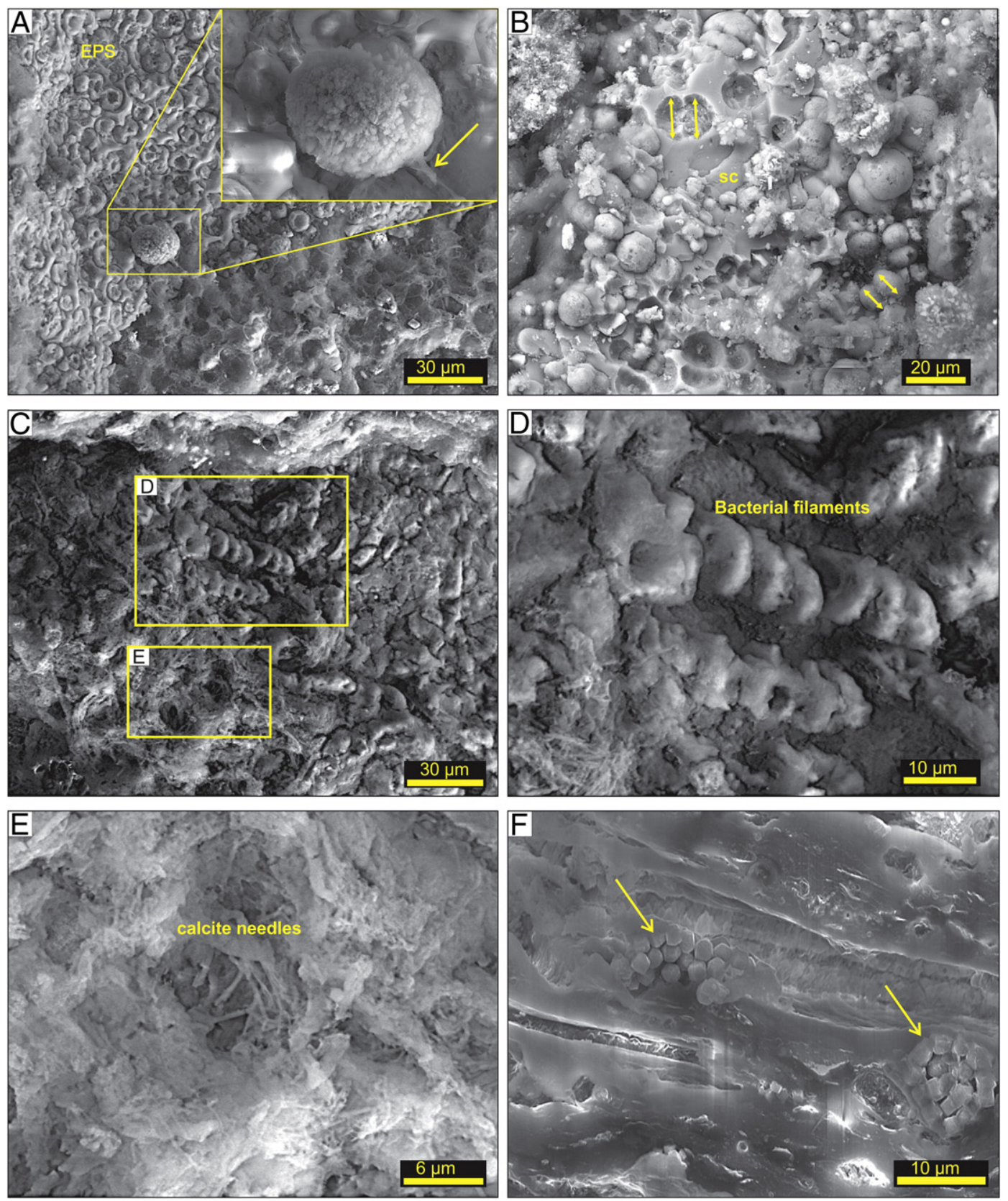

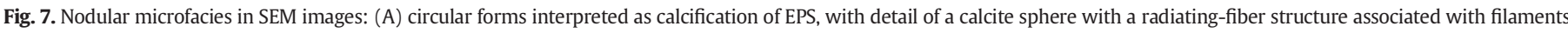

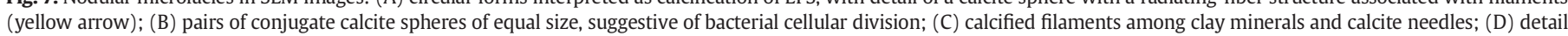
of calcified bacterial filaments; (E) detail of calcite needles; (F) clusters of framboidal pyrite among biofilms (yellow arrows), at $136.35 \mathrm{~m}$. 
(spherulites) associated with filaments generate an irregular substrate. The clay films rich in organic matter also contain acicular calcite crystals, spiral crystals and clusters of framboidal pyrite.

\subsubsection{Interpretation}

The relationship between the nodules and laminations suggests that it is an eodiagenetic feature that formed early in, or simultaneously with, the deposition of the laminites, based on their deformation of the lenses of micritic and organic matter matrix. The internal silicification in the nodules is interpreted as being syndepositional or early diagenetic stage, possibly related to an increase in evaporation and a decrease in $\mathrm{pH}$, thereby providing conditions for the concentration of silica in solution and biogenic precipitation of quartz (Pufahl, 2010). The presence of gypsum and pyrite suggests high salinity and low oxygen content, favorable for activity of sulfate-reducing bacteria and for sulfide precipitation within the biofilms. The spherical and elongated peloidal shapes are interpreted as clusters of precipitated calcium carbonate nanospheres in the EPS of bacterial colonies, whose metabolic activity affected the physicochemical conditions of the environment and provided the calcium carbonate precipitation. The association of biofilms with the substrate formed by the fabric of spherical features supports the interpretation that this structure was the product of the calcification of the EPS matrix. The other shapes of the calcite crystals, i.e., needles, microspheres and filaments also reinforce the biogenic interpretation of the carbonates. The pairs of calcite spheres with similar shapes and sizes suggest that they represent prokaryotic organisms of coccoid undergoing cellular division by multiple fission.

\subsection{Planar laminated microfacies}

\subsubsection{Description}

The planar laminated microfacies is characterized by micrite with planar parallel lamination with concordant discontinuous dark lenses of organic matter. Lamination is given by dark micritic and light microsparitic lenses. The organic particles are pyritized as indicated by the distribution of iron and sulfur (Fig. 8). The matrix is formed by euhedral to subhedral calcite micro-rhombohedrons associated with the presence of bacterial filaments and expressive amounts of EPS (Fig. 9). Alveolar structures with spherical calcite are preserved in the core nucleus in association with the organic matter.

\subsubsection{Interpretation}

Calcite rhombohedrons are presumably the product of biologicallyinduced precipitation by bacterial activity in an EPS-enriched substrate. The organic mucilage and the environmental conditions, such as the $\mathrm{CO}_{2}$ pressure, $\mathrm{CO}_{2}$ outgassing, hydrodynamic energy, $\mathrm{pH}$ and alkalinity, may explain the morphology and composition of the minerals that vary from rhombohedrons to spheres (Braissant et al., 2003). In Shark Bay, Australia, the precipitation of euhedral to subhedral crystals is occurring directly on the microbial EPS of the substrate (Jahnert et al., 2012). The discontinuous nature of the organic-rich lenses and the absence of gypsum suggest that this microfacies was deposited during periods of relatively high water levels. Sporadic input of freshwater to the system would have prevented the precipitation of gypsum and increased oxidation, resulting in poor preservation of organic matter.

\subsection{Crustiform microfacies}

\subsubsection{Description}

The crustiform microfacies is characterized by prismatic calcite crystals that form palisades enveloped in biofilms separated by laminites with micritic matrix. Clusters of spherical to subspherical calcite and crystals with a dendritic geometry are present in the biofilms overlapping the prismatic calcite crystals (Fig. 10).

\subsubsection{Interpretation}

The crustiform microfacies is localized in levels suggesting that it is a depositional feature associated with environmental variations. The crusts consisting of prismatic calcite crystals develop over a calcified substrate, probably biofilms ( $c f$. Riding, 2011). The morphology of crystal layers is similar to the bacterial shrubs of Chafetz and Guidry (1999). These shapes developed in aqueous environments with high energy, high concentrations of $\mathrm{CaCO}_{3}$, significant loss of $\mathrm{CO}_{2}$ (outgassing) and high salinity (Folk and Chafetz, 1983; Chafetz and Folk, 1984; Chafetz and Guidry, 1999). It is noteworthy that the presence of gypsum (Table 2) suggests deposition in arid hypersaline conditions. An alternate explanation for the crystalline crusts is the filling of voids between lenses by aragonite crystals recrystallized as calcite (Arp et al., 2003).

\section{Discussion}

A bacterial origin of the limestones of the Crato Fm. was previously suggested by Neumann et al. (2003), who interpreted anoxic conditions
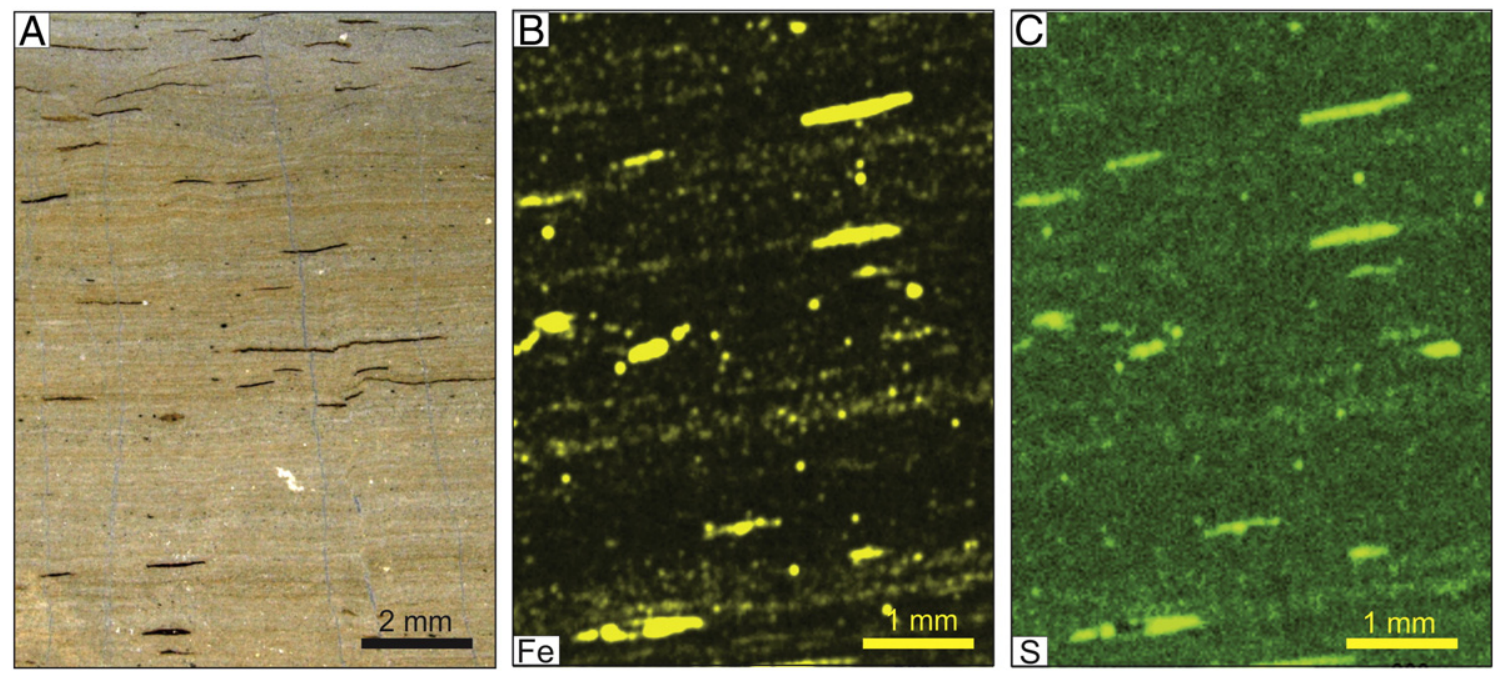

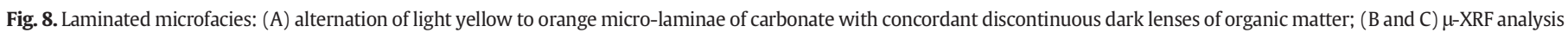
showing distribution of Fe and S associated with the organic matter, at $132.80 \mathrm{~m}$. 

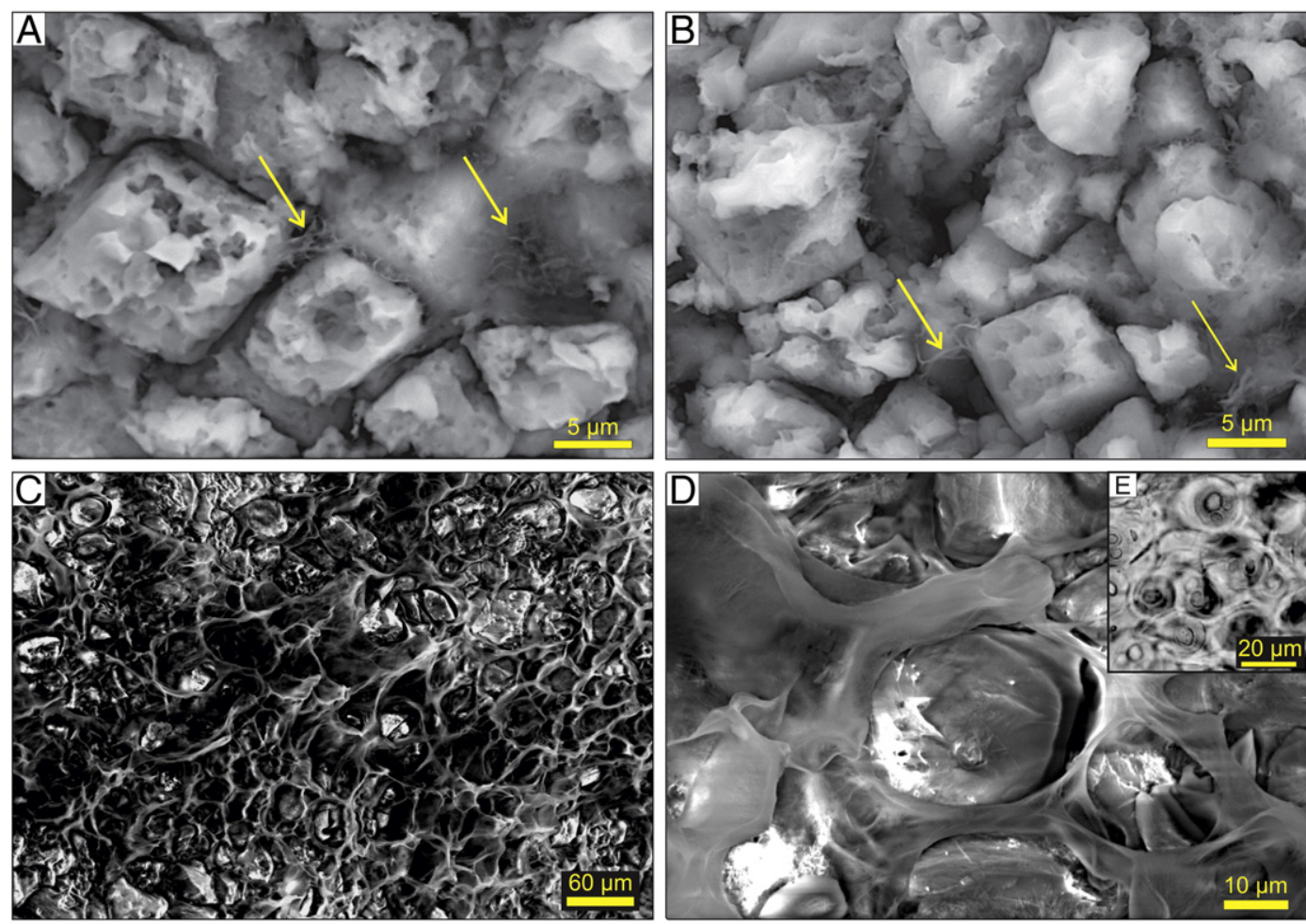

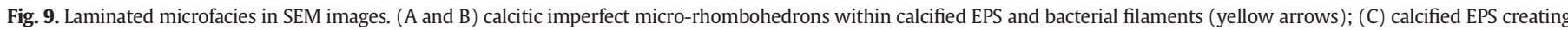

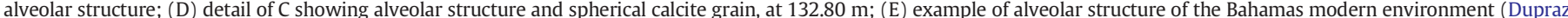
et al., 2004).

in the depositional environment based on the high fluorescence exhibited by AOM, although similar facies have been attributed to chemical precipitation in lacustrine environments without the involvement of microbial activity (Heimhofer et al., 2010).
Microscopic characterization of morphologic features strongly suggests microbial activity and organomineralization as the mechanisms that generated the Crato Formation limestones (see Figs. 5, 7,9 ). The fact that the primary organic component of these laminites
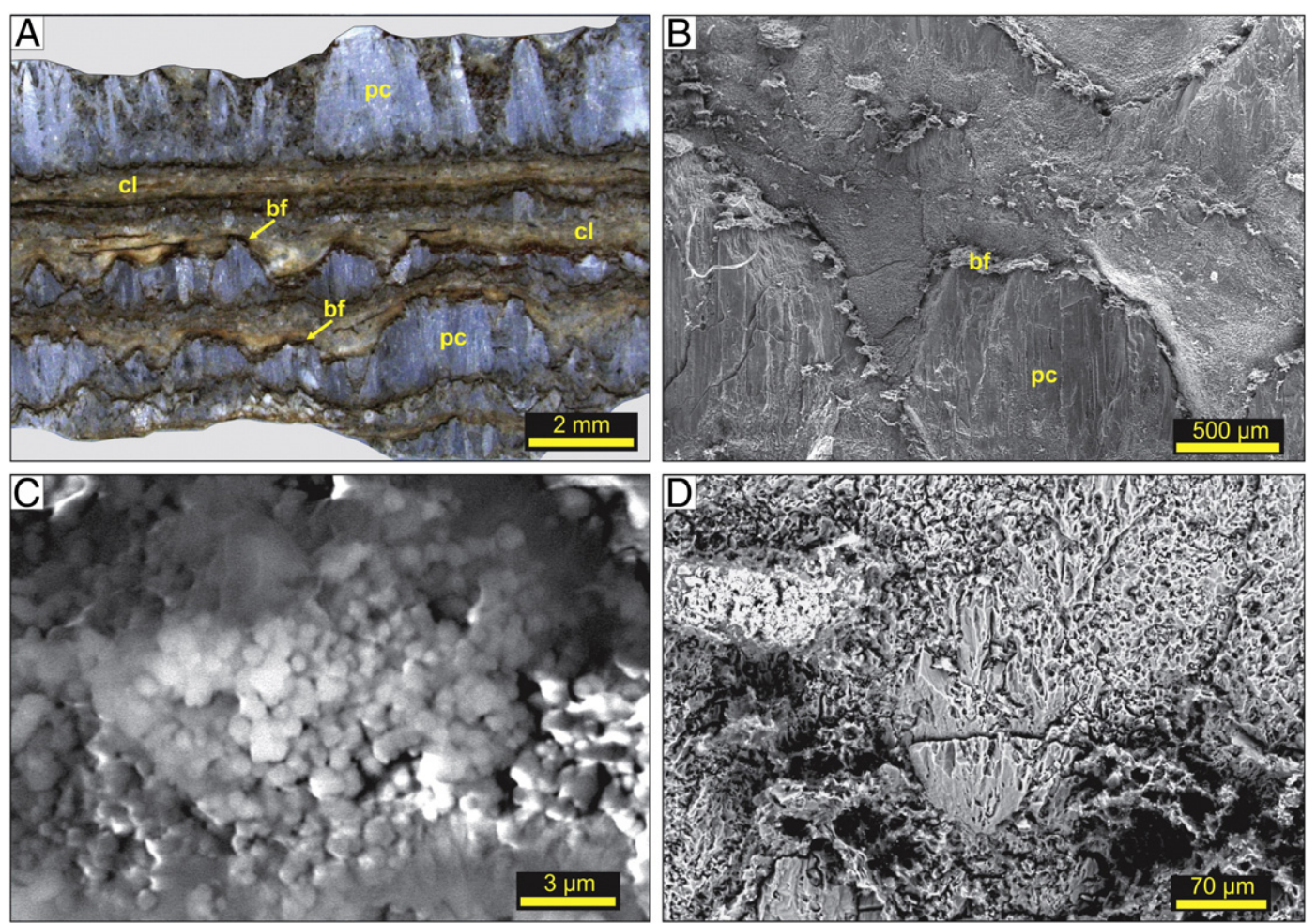

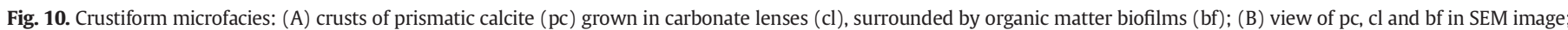
(C) SEM image showing aggregates of spherical to sub-spherical calcite crystals amid the biofilm; (D) calcite crystal with external shrub geometry, at 131.60 m. 
consists of amorphous organic matter (Table 1) also supports this interpretation.

The composition of the carbonate sediment exhibits expressive and pervasive contents of organic matter composed of organic aggregates, dissolved organic matter derivatives, peloidal material, shallow-water filamentous benthic bacteria (presumably cyanobacteria) and sulfatereducing bacteria associated with oxygen-deficient environments. The integrated analysis of this new information allowed a better understanding and a change in the previous "profundal carbonate" depositional model.

The recognition of microorganisms was based on a morphological comparison of modern fossil examples (Foster et al., 1989, 1990; Kazmierczak et al., 1996; Tribovillard, 1998; Kremer, 2006), including elongated and spiral filamentous and coccoid morphologies (Fig. 7). This comparison is possible only because this morphospecies remain with low or no morphological change over its evolutionary history (Schopf, 1992). According to Golubic and Hofmann (1976), the morphology of fossil specimens and their cell frequency distribution are similar to those of modern specimens. A comparison of the morphology, cellular division patterns, ecology and postmortem degradation sequence indicates that Precambrian and modern bacteria are identical (Knoll and Golubic, 1979). Based on this similarity and the specimens size ( 1 to $20 \mu \mathrm{m}$ ), it is inferred that the conjugated spherical pairs of coccoid form represent prokaryotic cells undergoing reproduction by multiple fission (Fig. 7).

Experiments with a gel matrix indicate that spherical shapes can be produced with or without the presence of bacterial cells (Chekroun et al., 2004; Turner and Jones, 2005). The formation of calcite spheres and several types of carbonate minerals can occur in association with a matrix of purified exopolysaccharides and amino acids as well as proteins and other organic products similar to EPS (Given and Wilkinson, 1985; Fernandez-Diaz et al., 1996; Braissant et al., 2003).

The presence of the EPS organic matrix indicates the biogenic in contribution to the precipitation of the carbonate minerals in the Crato Formation. The extraordinary preservation of the mucilage allowed the identification of the matrix, both in its primary organic and its calcified form. The AOM with the internal alveolar geometry (Fig. 4) is interpreted as the preserved EPS matrix (Pacton et al., 2012; Bahniuk et al., 2015). The structure formed by the fabric of spherical features in the nodular laminite microfacies (Fig. 9) is also interpreted as having resulted from the calcification of the EPS matrix. The EPS matrix in the planar laminated microfacies is virtually identical to that observed in modern microbial mats in an alkaline hypersaline lake on Eleuthera Island, Bahamas (Dupraz et al., 2004). This type of alveolar matrix can be produced by a large variety of microorganisms and is associated with the activity of heterotrophic, autotrophic, sulfate-reducing, methanogenic, sulfide-oxidizing (Bosak and Newman, 2005; Braissant et al., 2007) and free-living bacteria (Kives et al., 2006). These communities usually form microbial mats, where the organisms are capable of producing organic material using only $\mathrm{CO}_{2}$ and sunlight. According to Dupraz et al. (2009), the presence of an EPS matrix is essential because it controls the diffusion and adsorption/complexation of calcium.

Microbial communities serve well as a model for investigating the interactions between microorganisms and minerals involving several metabolic processes in these substrates. Processes like photosynthesis, ammonification, denitrification and sulfate reduction, oxidation of sulfides, and methane generation can modify the $\mathrm{pH}$, alkalinity, ion availability and organic content of the depositional environment and promote in situ biological mineralization of carbonate (Dupraz et al., 2009). It is likely that biologically induced and influenced organic mineralization occurs intermittently and is controlled by changes in temperature, composition, alkalinity and salinity of the water body, as reported in the formation of stromatolites in marine environments (Reid et al., 2000; Visscher et al., 2000), particularly in microbialites formed in hypersaline environments (Jonkers et al., 2003; Dupraz et al., 2004; Vasconcelos et al., 2006; Jahnert et al., 2012).
The presence of filaments along the calcite rhombohedrons in the Crato limestones (Fig. 9) suggests that environmental changes imposed by these microorganisms may have been one factor that triggered the nucleation and precipitation of the crystals, thereby supporting the biologically induced mineralization. Examples of this type of mineralization were observed in marine environments (Reitner, 1993), microbial soil crusts (Defarge et al., 1999), laminated lithified mats in lagoons of a Pacific Ocean atoll (Defarge et al., 1996; Trichet et al., 2001) and Cretaceous mud mounds (Neuweiler et al., 1999, 2000). The microorganisms are preserved as coccoid and filamentous forms in the laminated rocks. The coccoid forms are represented by calcite microspheres (occasionally as radiating fibers), forming clusters between the organic biofilms and on the surfaces of EPS mucilage. The filamentous forms display elongated shapes and circular cross sections and are peloidal where present in the nodular microfacies or calcified in the rhythmite microfacies. The calcified or embedded filaments are very similar to those described by Pentecost and Riding (1986) and can be present, extra- and intracellular, on fibrous sheaths of polysaccharides and mucilage composed of EPS (Skinner and Jahren, 2004).

The spathic calcite crystals associated with the crusts in the crustiform laminite microfacies without microorganisms or EPS suggest a biologically influenced mineralization. Similar forms of spathic calcite are commonly found in travertine, tufa, hydrothermal seeps, botryoidal crusts, alkaline lake deposits, poorly lit deep waters and chemically differentiated environments (Folk and Chafetz, 1983; Chafetz and Folk, 1984; Chafetz and Guidry, 1999). Many examples of calcite crusts have been interpreted as microbial carbonates produced by bacterial communities (Riding, 2011), and some researchers who describe the crusts as cement admit the influence of bacterial activity in their formation (Macintyre, 1984; Macintyre and Marshall, 1988). The presence of these organisms is due to their ability to survive and adapt to drastic environmental changes (Kromkamp et al., 2007). Most eukaryotes such as micro- and macro-algae and invertebrates, which compete for space with or ingest microbial communities, do not survive in extreme environments (Fischer, 1965; Awramik, 1971, 1992; Walter and Heys, 1985; Riding, 2006).

The type and amount of organic matter in the microfacies allowed the identification of relationships between the biological productivity and the preservation of organic matter. The nodular, crustiform and rhythmic microfacies, which are characterized by better preservation of organic matter and the presence of gypsum and silicification, suggest deposition during arid periods. Periods of extreme drought were responsible for the formation of halite crystals preserved as pseudomorphs. These features were registered in outcrops and they are similar to the previously pseudomorphs published by Martill et al. (2007b). Evaporation and drops in water level promote increasing salinity and water temperatures, thereby making the environment hostile to predators and favoring the proliferation of AOM-producing organisms, such as bacteria and archaea. In contrast, during humid periods, grazing organisms proliferated and consumed the bacterial organic matter, thereby significantly reducing its preservation. The planar laminated microfacies are associated with these humid periods and are characterized by little preservation of organic matter and the absence of evaporite minerals.

The AOM particles, particularly those with high fluorescence, are of intrabasinal origin because they do not tolerate a significant sedimentary transport (Tyson, 1993). The other types of organic matter, such as the phytoclasts and miospores, which are extrabasinal, are more common in the planar laminated microfacies. The presence of wellpreserved tetrads and clusters of sporomorphs suggests that these particles were deposited in a short distance from the source and in a lowenergy depositional environment (Tyson, 1984). The low percentage of sporomorphs suggests a dry climate with sparse vegetation, corroborating a previous interpretation based on floristic associations (Neumann et al., 2003).

The absence of macrofossils and marine palynomorphs (such as dinoflagellates, acritarchs, foraminifera, and scolecodonts), the predominance 
of well-preserved AOM and the absence of alginate, a typically marine element, indicate that the carbonates of the Crato Formation were originated in a lacustrine environment with a dysoxic to anoxic bottom. The lake systems were most likely hydrologically closed (Carroll and Bohacs, 1999), wherein a negative water balance created a hypersaline environment that was hostile to metazoans and favored the development of bacterial mats in shallow water.

\section{Conclusions}

The Crato Formation limestones are essentially calcitic, composed of micritic matrix with micro- to nanometric rhombohedral crystals, spherical or acicular grains and alveolar structures. Conventional microscopic analyses allowed the identification of four microfacies: rhythmic, nodular, planar laminated and crustiform, within a continuous $7 \mathrm{~m}$ thick interval of laminated limestones.

In the rhythmic, nodular and planar laminated microfacies, there was evidence of organic minerals precipitated by microbial metabolic activity. The excellent preservation of the microorganisms morphologies allowed the fossil prokaryotes to be compared with modern examples. Calcified microorganisms include elongated and filaments, coccoid morphologies and abundant organic-enriched carbonate matrix suggesting an additional organomineralization of exopolymeric substances (EPS).

The crustiform microfacies, composed of spathic crystals, do not reveal any direct evidence for the deposition of a biogenic product. However, the absence of any crystallographic forms, and the association with the other microbial facies, suggests an extrinsic influence of organic activity in its genesis. This microfacies associated with gypsum indicates aridity with relatively low-water level during deposition. This extreme condition supports the probability that biologically-influenced mineralization prevailed over biologically-induced process. Well preserved enriched amorphous organic matter overlaps the crystals of the crustiform macrofacies producing corrosion on the top of prismatic calcite crystals, probably related to the organic acids.

The organic fraction of the total package is composed primarily of heterogeneous and homogenous AOM. The heterogeneous component has an internal alveolar structure and is associated with EPS preservation, whereas the homogenous form has no visible structure and may be a result of EPS degradation. Phytoclasts and miospores are also present and indicate an extrabasinal contribution, although the depositional environment was of low energy, supported on the basis of the presence of tetrad miospores.

The presence of calcified coccoid, filamentous bacteria and calcified biofilms are being considered as a product of biologically induced mineralization. On the other hand, the absence of microorganisms or EPS within the prismatic crystals crusts have being considered as biologically influenced mineralization. The carbonate depositional cycles have metric thickness while the crystalline crusts are centimetric layers. Thus, it is possible to estimate that more than $90 \%$ of the carbonates are generated in situ throughout biologically induced mineralization.

Carbonates from well cores better preserve the microscopic features necessary for the identification of its organic origin. Finally, this finding opens many lines of inquiry into the Aptian sections of the pre-salt interval in basins along the east coast of Brazil, which hold some similarities with the Crato limestones.

\section{Acknowledgements}

The authors thank the Stratigraphy and Sedimentology Network of Petrobras (0050.0023165.06.4) for supporting the project "Stratigraphic Analysis of the Alagoas Stage in the Araripe, Tucano-Jatoba, Parnaiba and Sanfranciscana Basins"; the Sao Paulo State Research Foundation (FAPESP 2004/15786-0) and the Brazilian National Council for Scientific and Technological Development (CNPq 476727/2004-9) for the support of research projects in the Araripe Basin; the Center for Geosciences
Applied to Petroleum Geology (UNESpetro) at the Sao Paulo State University (UNESP), Rio Claro campus, for providing the infrastructure and laboratory facilities for the petrography, scanning electronic microscopy and X-ray micro-fluorescence analysis; the Minerals and Rocks Analysis Laboratory of the Federal University of Parana (UFPR) for the X-ray diffraction analysis; and Petrobras Research Center for the organic geochemistry and palynofacies analysis.

We are grateful to Professor Thomas Fairchild for the discussion and improvements to the manuscript, to Dr. Virginio Neumann and Bruno Araujo for their overall support, Dra. Carla Araujo and Dr. Henrique Penteado for the reviews and insights to the study.

We thank Dr. Crisogono Vasconcelos and anonymous reviewer for their comments and suggestions that greatly improved this article.

\section{References}

Aloisi, G., et al., 2006. Nucleation of calcium carbonate on bacterial nanoglobules. Geology 34 (12), 1017-1020

Arp, G., Reimer, A., Reitner, J., 2003. Microbialite formation in seawater of increased alkalinity, Satonda Crater Lake, Indonesia. Journal of Sedimentary Research 73 (1), 105-127.

Assine, M.L., 1992. Análise estratigráfica da Bacia do Araripe, Nordeste do Brasil. Revista Brasileira de Geociências 22 (3), 289-300.

Assine, M.L., 2007. Araripe basin. Boletim de Geociencias da Petrobras 15 (2), 371-389.

Awramik, S.M., 1971. Precambrian columnar stromatolite diversity: reflection of metazoan appearance. Science 174 (4011), 825-827.

Awramik, S.M., 1992. The history and significance of stromatolites. In: Schidlowski, M. Kimberley, M.M., McKirdy, D.M., Trudinger, P.A. (Eds.), Early Organic Evolution: Implications for Energy and Mineral Resources. Springer, Berlin, pp. 435-449.

Bahniuk, A.M., et al., 2015. Development of microbial carbonates in the Lower Cretaceous Codó Formation (north-east Brazil): implications for interpretation of microbialite facies associations and palaeoenvironmental conditions. Sedimentology 62 (1), $155-181$.

Barling, N., Martill, D.M., Heads, S.W., Gallien, F., 2015. High fidelity preservation of fossil insects from the Crato Formation (Lower Cretaceous) of Brazil. Cretaceous Research 52 (Part B(0)), 605-622.

Bosak, T., Newman, D.K., 2005. Microbial kinetic controls on calcite morphology in supersaturated solutions. Journal of Sedimentary Research 75 (2), 190-199.

Bowler, J.M., Teller, J.T., 1986. Quaternary evaporites and hydrological changes, Lake Tyrrell, North-West Victoria. Australian Journal of Earth Sciences 33 (1), 43-63.

Braissant, O., Cailleau, G., Dupraz, C., Verrecchia, E.P., 2003. Bacterially induced mineralization of calcium carbonate in terrestrial environments: the role of exopolysaccharides and amino acids. Journal of Sedimentary Research 73 (3), 485-490.

Braissant, O., et al., 2007. Exopolymeric substances of sulfate-reducing bacteria: interactions with calcium at alkaline $\mathrm{pH}$ and implication for formation of carbonate minerals. Geobiology 5 (4), 401-411.

Carroll, A.R., Bohacs, K.M., 1999. Stratigraphic classification of ancient lakes: balancing tectonic and climatic controls. Geology 27 (2), 99-102.

Chafetz, H.S., Folk, R.L., 1984. Travertines: depositional morphology and the bacterially constructed constituents. Journal of Sedimentary Research 54 (1), 289-316.

Chafetz, H.S., Guidry, S.A., 1999. Bacterial shrubs, crystal shrubs, and ray-crystal shrubs: bacterial vs. abiotic precipitation. Sedimentary Geology 126 (1-4), 57-74.

Chekroun, K.B., et al., 2004. Precipitation and growth morphology of calcium carbonate induced by Myxococcus xanthus: implications for recognition of bacterial carbonates. Journal of Sedimentary Research 74 (6), 868-876.

Combaz, A., 1980. Les Kérogenes vus au microscope. In: Durand, B. (Ed.), Kerogen Insoluble Organic Matter from Sedimentary Rocks. Editions Technip.

De Philippis, R., Margheri, M.C., Materassi, R., Vincenzini, M., 1998. Potential of unicellular cyanobacteria from saline environments as exopolysaccharide producers. Applied and Environmental Microbiology 64 (3), 1130-1132.

De Philippis, R., Sili, C., Paperi, R., Vincenzini, M., 2001. Exopolysaccharide-producing cyanobacteria and their possible exploitation: a review. Journal of Applied Phycology 13 (4), 293-299.

Dean, W.E., Fouch, T.D., 1983. Lacustrine environment. In: Scholle, P.A., Bebout, D.G., More, C.H. (Eds.), Carbonate Depositional Environments. Am. Ass. Petrol. Geol., Memoir vol. 33, pp. 97-130.

Defarge, C., et al., 1996. Texture of microbial sediments revealed by cryo-scanning electron microscopy. Journal of Sedimentary Research 66 (5), 935-947.

Defarge, C., Issa, O.M., Trichet, J., 1999. Field emission cryo-scanning electron microscopy of organic matter and organomineral associations. Application to microbiotic soil crusts. Comptes Rendus de l'Academie des Sciences Series IIA Earth and Planetary Science 9 (328), 591-597.

Demicco, R.V., Hardie, L.A., 1994. Sedimentary Structures and Early Diagenetic Features of Shallow Marine Carbonate Deposits. Atlas Series 1. SEPM (265 pp.).

Dupraz, C., Visscher, P.T., Baumgartner, L., Reid, R., 2004. Microbe-mineral interactions: early carbonate precipitation in a hypersaline lake (Eleuthera Island, Bahamas). Sedimentology 51 (4), 745-765.

Dupraz, C., et al., 2009. Processes of carbonate precipitation in modern microbial mats. Earth-Science Reviews 96 (3), 141-162.

Fernandez-Diaz, L., Putnis, A., Prieto, M., Putnis, C.V., 1996. The role of magnesium in the crystallization of calcite and aragonite in a porous medium. Journal of Sedimentary Research 66 (3), 482-491. 
Fischer, A.G., 1965. Fossils, early life, and atmospheric history. Proceedings of the National Academy of Sciences 53 (6), 1205-1215.

Flügel, E., 2004. Microfacies of Carbonate Rocks: Analysis, Interpretation and Application. Springer, Berlin (976 pp.).

Folk, R.L., Chafetz, H.S., 1983. Pisoliths (pisoids) in Quaternary travertines of Tivoli, Italy. In: Peryt, T.M. (Ed.), Coated Grains. Springer, New York, pp. 474-487.

Foster, C.B., Reed, J.D., Wicander, R., 1989. Gloeocapsomorpha prisca Zalessky, 1917: a new study: part I: taxonomy, geochemistry, and paleoecology. Geobios 22 (6), 735-759.

Foster, C.B., Wicander, R., Reed, J.D., 1990. Gloeocapsomorpha prisca Zalessky, 1917: a new study part II: origin of kukersite, a new interpretation. Geobios 23 (2), 133-140.

Freire, P.T.C., et al., 2013. Pyritization of fossils from the Lagerstätte Araripe Basin, Northeast Brazil, from the Cretaceous period. In: Whitley, N., Vinsen, P.T. (Eds.) Pyrite: Synthesis, Characterization and Uses. Nova Science Publishers, New York, pp. 123-140.

Given, R.K., Wilkinson, B.H., 1985. Kinetic control of morphology, composition, and mineralogy of abiotic sedimentary carbonates. Journal of Sedimentary Research 55 (1), 109-119.

Golubic, S., Hofmann, H.J., 1976. Comparison of Holocene and mid-Precambrian Entophysalidaceae (Cyanophyta) in stromatolitic algal mats: cell division and degradation. Journal of Paleontology 50, 1074-1082.

Heimhofer, U., et al., 2010. Deciphering the depositional environment of the laminated Crato fossil beds (Early Cretaceous, Araripe Basin, North-eastern Brazil). Sedimentology 57, 677-694.

Jahnert, R., de Paula, O., Collins, L., Strobach, E., Pevzner, R., 2012. Evolution of a coquina barrier in Shark Bay, Australia by GPR imaging: architecture of a Holocene reservoir analog. Sedimentary Geology 281 (0), 59-74.

Jonkers, H.M., et al., 2003. Structural and functional analysis of a microbial mat ecosystem from a unique permanent hypersaline inland lake:'La Salada de Chiprana'(NE Spain). FEMS Microbiology Ecology 44 (2), 175-189.

Kazmierczak, J., Coleman, M.L., Gruszczynski, M., 1996. Cyanobacterial key to the genesis of micritic and peloidal limestones in ancient seas. Acta Palaeontologica Polonica 41, 319-330.

Kives, J., Orgaz, B., SanJosé, C., 2006. Polysaccharide differences between planktonic and biofilm-associated EPS from Pseudomonas fluorescens B52. Colloids and Surfaces B: Biointerfaces 52 (2), 123-127.

Knoll, A.H., Golubic, S., 1979. Anatomy and taphonomy of a Precambrian algal stromatolite. Precambrian Research 10 (1), 115-151.

Kremer, B., 2006. Mat-forming coccoid cyanobacteria from early Silurian marine deposits of Sudetes, Poland. Acta Palaeontologica Polonica 51 (1), 143-154.

Kromkamp, J.C., et al., 2007. Resistance to burial of cyanobacteria in stromatolites. Aquatic Microbial Ecology 48, 123-130.

Macintyre, I.G., 1984. Extensive submarine lithification in a cave in the Belize barrier reef platform. Journal of Sedimentary Research 54 (1), 221-235.

Macintyre, I., Marshall, J., 1988. Submarine lithification in coral reefs: some facts and misconceptions. 6th Int Coral Reef Symp. Procedings, Townsville, Australia, pp. 263-272.

Martill, D.M., Bechly, G., Loveridge, R.F. (Eds.), 2007a. The Crato Fossil Beds of Brazil Window Into an Ancient World. Cambridge University Press, New York (625 pp.).

Martill, D.M., Loveridge, R., Heimhofer, U., 2007b. Halite pseudomorphs in the Crato Formation (Early Cretaceous, Late AptianeEarly Albian), Araripe Basin, northeast Brazil: further evidence for hypersalinity. Cretaceous Research 28, 613-620.

Matos, R.M.D., 1992. The northeast Brazilian rift system. Tectonics 11 (4), 766-791.

Matos, R.M.D., 1999. History of the northeast Brazilian rift system: kinematic implications for the break-up between Brazil and West Africa. In: Cameron, N.R., Bate, R.H., Clure, V.S. (Eds.), The Oil and Gas Habitats of the South Atlantic. Geological Society of London, pp. 55-73.

Neumann, V.H.M.L., 1999. Estratigrafia, Sedimentologia, Geoquímica y Diagénesis de los Sistemas Lacustres Aptienses-Albienses de lá Cuenca de Araripe (Nororeste do Brasil) Tese de Doctorado Thesis Universitat de Barcelona, Barcelona (233 pp.).
Neumann, V.H., Borregob, A.G., Cabrerac, L., Dinod, R., 2003. Organic matter composition and distribution through the Aptian-Albian lacustrine sequences of the Araripe Basin, northeastern Brazil. International Journal of Coal Geology 54, 21-40.

Neuweiler, F., et al., 1999. Petrology of Lower Cretaceous carbonate mud mounds (Albian, $\mathrm{N}$. Spain): insights into organomineralic deposits of the geological record. Sedimentology 46 (5), 837-859

Neuweiler, F., Rutsch, M., Geipel, G., Reimer, A., Heise, K.-H., 2000. Soluble humic substances from in situ precipitated microcrystalline calcium carbonate, internal sediment, and spar cement in a Cretaceous carbonate mud-mound. Geology 28 (9), 851-854.

Pacton, M., et al., 2012. Going nano: a new step toward understanding the processes governing freshwater ooid formation. Geology 40 (6), 547-550.

Pentecost, A., Riding, R., 1986. Calcification in cyanobacteria. In: Leadbeater, B.S.C., Riding, R. (Eds.), Biomineralization in Lower Plants and Animals. Clarendon Press, Oxford, pp. 73-90.

Pufahl, P.K., 2010. Bioelemental sediments. In: James, N.P., Dalrymple, R.W. (Eds.), Facies Models 4. Geological Association of Canada, pp. 477-504.

Reid, R.P., et al., 2000. The role of microbes in accretion, lamination and early lithification of modern marine stromatolites. Nature 406 (6799), 989-992.

Reitner, D.D.J., 1993. Modern cryptic microbialite/metazoan facies from Lizard Island (Great Barrier Reef, Australia) formation and concepts. Facies 29 (1), 3-39.

Richert, L., et al., 2005. Characterization of exopolysaccharides produced by cyanobacteria isolated from Polynesian microbial mats. Current Microbiology 51 (6), 379-384.

Riding, R., 2006. Microbial carbonate abundance compared with fluctuations in metazoan diversity over geological time. Sedimentary Geology 185 (3-4), 229-238.

Riding, R., 2011. Reefal microbial crusts. Encyclopedia of Modern Coral Reefs: Structure, Form and Process. Springer, Heidelberg, pp. 911-915.

Schopf, J.W., 1992. Paleobiology of the Archean. In: Schopf, J.W., Klein, C. (Eds.), The Proterozoic Biosphere: A Multidisciplinary Study. Cambridge Univ. Press, Cambridge, pp. 25-39.

Skinner, H.C.W., Jahren, A.H., 2004. Biomineralization. In: Schlesinger, W.H. (Ed.), Treatise on GeochemistryBiogeochemistry vol. 8. Elsevier, pp. 117-184.

Stal, L.J., 2000. Microbial mats and stromatolites. In: Whitton, B.A., Potts, M. (Eds.), The Ecology of Cyanobacteria. Their Diversity in Time and Space. Kluwer Academic Publishers, Dordrecht, The Netherlands, pp. 61-120.

Stal, L.J., 2003. Microphytobenthos, their extracellular polymeric substances, and the morphogenesis of intertidal sediments. Geomicrobiology Journal 20 (5), 463-478.

Tribovillard, N.P., 1998. Cyanobacterially generated peloids in laminated, organic-matter rich, limestones: an unobtrusive presence. Terra Nova 10 (3), 126-130.

Trichet, J., Défarge, C., Tribble, J., Tribble, G., Sansone, F., 2001. Christmas Island lagoonal lakes, models for the deposition of carbonate-evaporite-organic laminated sediments. Sedimentary Geology 140 (1), 177-189.

Turner, E.C. Jones, B., 2005. Microscopic calcite dendrites in cold-water tufa: implications for nucleation of micrite and cement. Sedimentology 52, 1043-1066.

Tyson, R.V., 1984. Palynofacies investigation of Callovian (Middle Jurassic) sediments from DSDP Site 534, Blake-Bahama Basin, western Central Atlantic. Marine and Petroleum Geology 1 (1), 3-13.

Tyson, R.V., 1993. Palynofacies analysis. In: Jenkins, D.J. (Ed.), Applied Micropalaeontology. Kluwer Academicx Publishers, Dordrecht, pp. 153-191.

Tyson, R.V., 1995. Sedimentary Organic Matter: Organic Facies and Palynofacies. Chapman \& Hall, London (615 pp.).

Vasconcelos, C., et al., 2006. Lithifying microbial mats in Lagoa Vermelha, Brazil: modern Precambrian relics? Sedimentary Geology 185 (3-4), 175-183.

Visscher, P.T., Reid, R.P., Bebout, B.M., 2000. Microscale observations of sulfate reduction: correlation of microbial activity with lithified micritic laminae in modern marine stromatolites. Geology 28 (10), 919-922.

Walter, M., Heys, G., 1985. Links between the rise of the Metazoa and the decline of stromatolites. Precambrian Research 29 (1), 149-174. 